\title{
Uterine secretome and its modulation in rat (Rattus norvegicus)
}

\author{
Sumit Bhutada ${ }^{1}$, R R Katkam ${ }^{1}$, Tarla Nandedkar ${ }^{1}$, S M Metkari ${ }^{2}$, U K Chaudhari ${ }^{1}$, Sneha Varghese ${ }^{1}$, \\ S D Kholkute ${ }^{1}$ and Geetanjali Sachdeva ${ }^{1}$ \\ ${ }^{1}$ Primate Biology Division and ${ }^{2}$ Experimental Animal Facility, National Institute for Research in Reproductive Health, \\ Indian Council of Medical Research, JM Street, Parel, Mumbai 400012, India
}

Correspondence should be addressed to G Sachdeva; Email: sachdevag@nirrh.res.in

\begin{abstract}
The present study identifies uterine fluid (UF) proteins that display differential abundance during the embryo-permissive phase in nonconception and conception cycles in rats. UF samples were collected from nonpregnant rats in the proestrous $(n=17)$ and metestrous $(n=18)$ phases and also from pregnant $(n=17)$ and pseudopregnant $(n=17)$ rats on day 4 post coitus. UF protein profile in the metestrous phase was compared with that in the proestrous phase. Similarly, UF protein profile of the pregnant rats was compared with that of the pseudopregnant rats. Two-dimensional PAGE, followed by densitometric analysis of the paired protein spots, revealed differential abundance of 44 proteins in the metestrous phase, compared with that in the proestrous phase. Of these, 29 proteins were identified by matrix-assisted laser desorption/ionization time-of-flight or liquid chromatography-tandem mass spectrometry. Functional groups such as proteases, protease inhibitors, and oxidoreductases were enriched in differentially abundant proteins. Total protease activity in UF was found to be significantly $(P<0.05 ;$ t-test) higher in the proestrous phase, compared with that in the metestrous phase. Furthermore, 41 UF proteins were found to be differentially abundant in pregnant rats, compared with pseudopregnant rats. Of these, 11 proteins could be identified. Immunoblotting analysis confirmed significantly higher $(\boldsymbol{P}<0.05 ; \boldsymbol{t}$-test $)$ abundance of $\boldsymbol{\beta}$-actin, Rho-specific guanine nucleotide dissociation inhibitor alpha (Rho-GDI $\alpha$ ), and peroxiredoxin-2 and -6 in the metestrous phase, compared with that in the proestrous phase. Compared with pseudopregnant rats, pregnant rats had significantly higher $(P<0.05 ; t$-test $)$ levels of UF $\beta$-actin and Rho-GDI $\alpha$. Furthermore, these proteins could be detected in the culture supernatants of endometrial epithelial cell lines, thereby providing an evidence of their secretion from endometrial epithelial cells. Data obtained from the study expand our knowledge on the uterine milieu that favours embryo implantation.

Reproduction (2013) 146 13-26
\end{abstract}

\section{Introduction}

Reproductive tract fluids provide an optimal microenvironment for movement of spermatozoa and ova. These fluids also provide a conducive medium for fertilization, mobility, and development of pre-implantation embryos (Aguilar \& Reyley 2005). It is believed that the identification of the constituents of reproductive tract fluids can provide significant insights into mechanisms underlying various reproductive events. Attempts have been made to screen follicular fluid, cervical-vaginal fluid, amniotic fluid, uterine fluid (UF), etc., for the presence of specific proteins, presumed to be of relevance in reproductive functions (Jozwik et al. 1999, Inagaki et al. 2003, Bedaiwy et al. 2007, Heng et al. 2008, Keeler et al. 2009). However, these studies focused only on the particular proteins of interest. Recent advances in proteomic technologies have spurred several efforts toward the identification of the total protein repertoire of human reproductive tract fluids (Tsangaris et al. 2006, Casado-Vela et al. 2009, Zegels et al. 2009, Jarkovska et al. 2010). As a result, now there exists substantial information about the proteins, which collectively contribute toward creating extracellular microenvironments in vicinity of various reproductive tissues.

Investigations to assess the significance of UF in female reproduction date back to 1970s. Proteins, carbohydrates, and other metabolites secreted by the endometrial cells and components of serum transudates are known to be the major constituents of the UF. It is postulated that these components serve as regulators of endometrial cell volume and nutrition, and also as the mediators of intracellular and extracellular communication (Hafez 1977). UF also functions as a transport and support medium for spermatozoa and embryos (Salleh et al. 2005). It provides an immunosuppressive environment for implantation, as well as nutrition to a growing embryo (Halperin et al. 1998). It was previously believed that the embryo derives its nutrition from uterine luminal fluid only until it establishes contact with the maternal vasculature. However, it has become apparent now that uterine glands and their secretions continue playing an active role in terms of nutrition till the first trimester of 
pregnancy in humans (Burton et al. 2002). Levels of leukemia inhibitory factor, mucin-1, glycodelin, vascular endothelial growth factor, and proprotein convertase $5 / 6$ in the UF were found to be suboptimal in women with infertility (Mackenna et al. 1993, Aplin et al. 1996, Mikolajczyk et al. 2006, Hannan et al. 2011, Heng et al. 2011). These studies showed the utility of UF analysis in gauging endometrial function.

In recent years, few proteomics-based investigations have been undertaken to investigate the UF protein complement of humans (Parmar et al. 2008, Scotchie et al. 2009, Hannan et al. 2010) and some animal species such as pigs and ewes (Lee et al. 1998, Koch et al. 2010). These studies revealed cycle- or pregnancy-dependent modulation in the UF protein profile. However, to our knowledge, there are no reports on the global protein profile of rat UF. Considering the utility of rodent models in assessing the functional relevance of human genes/ proteins associated with endometrial receptivity, we considered it worthwhile to identify the proteins that define the luminal milieu of uterine cavity in rats (Rattus norvegicus). Protein profiles of the proestrous and metestrous phase UF samples were compared. These investigations were expected to aid in the identification of secreted proteins that may contribute to endometrial preparation toward receptivity. UF proteomes of pregnant and pseudopregnant rats were also compared with an aim to identify those proteins that modulate the uterine microenvironment during embryo attachment.

\section{Materials and methods}

The study was approved by the Institute's Animal Ethics Committee. Rats ( $R$. norvegicus) were housed in individual cages in a temperature- and humidity-controlled room with a $14 \mathrm{~h}$ light: $10 \mathrm{~h}$ darkness cycle between 23 and $25{ }^{\circ} \mathrm{C}$. Vaginal smears of sexually mature, healthy female rats (200-250 g body weight) were checked daily for three consecutive estrous cycles and only those animals with regular cyclicity were selected.

\section{Nonconception cycle}

Nonpregnant animals were allotted to two groups proestrous $(n=17)$ and metestrous $(n=18)$ based on the vaginal smear examination. The animals were killed by $\mathrm{CO}_{2}$ asphyxiation and their uterine horns were quickly excised for retrieval of the UF. For the proestrous group, samples collected from 11 animals were used for 2D proteomics studies (three pools with each containing a pooled sample of three to four animals), three animals for immunoblot analysis, and three animals for protease assays. For the metestrous group, UF samples of 12 animals were investigated for 2D proteomics, three animals for immunoblot analysis, and three animals for protease assays.

\section{Conception cycle}

The presence of a sperm plug in the vaginal smears of female rats caged with male rats confirmed mating and was considered as day 1 post coitus or day 1 of pregnancy. Pseudopregnancy was induced by caging adult female rats with vasectomized males. Continuation in the diestrous phase for three consecutive days was an indicator of pseudopregnancy. Pregnant $(n=17)$ and pseudopregnant $(n=17)$ animals were killed on day 4 post coitus. Uterine horns were excised from pregnant and pseudopregnant rats. For both the groups, UF samples from 11 animals were used for 2D proteomics studies, three for immunoblot analysis, and three for protease assays. For immunoblot and protease assays, individual samples were used.

\section{Collection of UF and uterine tissues}

Both the uterine horns were ligated at their tips and also at their conjoint portion. Associated fat and connective tissues were removed from the uterine horns. Each horn was flushed at one end with $0.5 \mathrm{ml}$ saline containing $1 \times$ protease inhibitor cocktail (Amersham Biosciences) and fluid was collected from the other end of the horn. Total volume retrieved from both the horns was around $1.05 \mathrm{ml}$. For protease assays, fluid samples were collected in saline without protease inhibitors. After collection, samples were immediately centrifuged at $135 \mathrm{~g}$ for $30 \mathrm{~min}$ at $4{ }^{\circ} \mathrm{C}$ to remove cells or debris, and the supernatants were stored at $-20{ }^{\circ} \mathrm{C}$ for proteomic analysis. Protein amount (100-120 $\mu \mathrm{g})$ recovered from the UF of one animal was insufficient for 2D proteomic analysis; hence, samples were pooled from three or four animals presenting the same condition (proestrous or metestrous phases/pregnancy or pseudopregnancy). Samples were pooled only after confirmation by the histological analysis of the uterine sections of each animal. For histological and immunohistochemical analysis, uterine horns were collected in PBS $(137 \mathrm{mM}$ $\mathrm{NaCl}, 2.7 \mathrm{mM} \mathrm{KCl}, 10 \mathrm{mM} \mathrm{Na} 2 \mathrm{HPO}_{4} 2 \cdot \mathrm{H}_{2} \mathrm{O}$, and $2 \mathrm{mM}$ $\mathrm{KH}_{2} \mathrm{PO}_{4}$ ) and fixed in $10 \%$ buffered formalin for $24 \mathrm{~h}$, washed in $70 \% \mathrm{vol} / \mathrm{vol}$ ethanol, passed through ascending grades of ethanol followed by xylol (xylene:ethanol, $1: 1)$, and xylene treatment. Tissues were then embedded in paraffin wax (Merck Limited). Serial sections of $5 \mu \mathrm{m}$ were cut and stained with hematoxylin/eosin for histological analysis.

\section{Protein extraction}

UF proteins were concentrated by acetone precipitation. Protein pellets were solubilized in rehydration buffer containing $9 \mathrm{M}$ urea, $10 \mathrm{mM}$ dithiothreital (DTT), and 0.5\% 3-((3-chlamidopropyl) dimethylammonio)-1-propanesulfonate. Protein concentration was determined using Bradford's assay (Bradford 1976). Samples to be 
compared were subjected to isoelectric focusing and SDS-PAGE in the same run. Immobiline $\mathrm{pH}$ gradient strips (Amersham Pharmacia Biotech) of $11 \mathrm{~cm}$ length (in the linear range of $\mathrm{pH} \mathrm{4-7)} \mathrm{were} \mathrm{actively} \mathrm{rehydrated}$ with $200 \mu$ g protein in rehydration buffer containing $20 \mu \mathrm{l}$ DeStreak solution (Amersham Pharmacia), $4 \mu \mathrm{l}$ ampholine (Amersham Pharmacia) at $50 \mathrm{~V}$ for $16 \mathrm{~h}$, followed by isoelectric focusing at $100 \mathrm{~V}$ for $1 \mathrm{~h}, 250 \mathrm{~V}$ for $1 \mathrm{~h}$, $500 \mathrm{~V}$ for $1 \mathrm{~h}, 6000 \mathrm{~V}$ for $2 \mathrm{~h}$, and $8000 \mathrm{~V}$ for $4 \mathrm{~h}$ in a IEF cell (Bio-Rad) at $20^{\circ} \mathrm{C}$. Strips with focused proteins were incubated in equilibration buffer I $(50 \mathrm{mM}$ Tris- $\mathrm{HCl}, \mathrm{pH}$ 8.8, $6 \mathrm{M}$ urea, $30 \%$ glycerol, and $65 \mathrm{mM}$ DTT) for reduction and in equilibration buffer II $(50 \mathrm{mM}$ Tris-HCl, $\mathrm{pH}$ 8.8, $6 \mathrm{M}$ urea, 30\% glycerol, and $250 \mathrm{mM}$ iodoacetamide) for alkylation. Proteins were resolved in the second dimension by $12 \%$ SDS-PAGE and 2D gels were stained using a mass-spectrometry-compatible silver staining method (Shevchenko et al. 1996). Stained gels were scanned using ImageScanner III (GE Healthcare Biosciences, Pittsburgh, PA, USA).

\section{Densitometric analysis of $2 D$ gels}

For each group, to be compared with its counterpart (proestrous with metestrous; pregnant with pseudopregnant), three representative 2D gels were prepared using the respective samples, each pooled from three or four animals. Each gel representing the proestrous group was compared with all the three gels representing the metestrous group, thus generating nine data sets. A similar strategy was adopted for the comparative analysis of 2D gels representing the pregnant and pseudopregnant groups. Densitometric analysis of gels was carried out using IMP software, version 6 (GE Healthcare Biosciences) to identify differentially abundant proteins. To normalize the total protein load across the gels, total gel spot volume was calculated. Each of the paired spots was analyzed for its volume. Paired spots, which showed twofold or more change in their volume (when compared between proestrous and metestrous gels or between pregnant and pseudopregnant gels), were considered to be differentially abundant.

\section{Excision and identification of spots}

Differentially abundant spots were manually excised from 2D gels and trypsin digested according to the protocol published previously (Shevchenko et al. 1996). In brief, excised gel plugs were washed four times with Milli Q water by centrifugation at $9391 \boldsymbol{g}$ for $10 \mathrm{~min}$ each. Destaining of the gel plugs was carried out in freshly prepared Farmer's reagent $(30 \mathrm{mM}$ potassium ferricyanide and $100 \mathrm{mM}$ sodium thiosulfate) for $20 \mathrm{~min}$ at room temperature with shaking until they became colorless. After washing twice with water, gel plugs were incubated with $25 \mathrm{mM}$ ammonium bicarbonate (ABC) for $15 \mathrm{~min}$ at RT. This was followed by dehydration in $50 \%$ acetonitrile (ACN) and rehydration in $25 \mathrm{mM} \mathrm{ABC}$ for $5 \mathrm{~min}$ each. Gel plugs were dehydrated first in $50 \% \mathrm{ACN}$ and then in $100 \% \mathrm{ACN}$. Proteins were reduced to peptides by incubating the dried gel plugs in $4 \mathrm{ng} / \mu \mathrm{l}$ sequencing grade trypsin (Sigma-Aldrich) in 20-25 $\mu \mathrm{l}$ reaction volume for $16 \mathrm{~h}$ at $37^{\circ} \mathrm{C}$. Peptides were eluted from gel matrix by mincing the gel plugs. Peptide extraction was done, first in $50 \%$ ACN with $0.1 \%$ TFA, then in $50 \%$ ACN with $0.5 \%$ TFA, and finally in $50 \%$ ACN with $1 \%$ TFA. Supernatants containing tryptic peptides were collected, lyophilized, and stored at $-20{ }^{\circ} \mathrm{C}$ until MALDI-TOF/TOF or LCMS/ MS analysis.

Digested peptides, suspended in $2 \mu \mathrm{I} 50 \%$ ACN containing $1.0 \%$ TFA, were spotted onto a MALDITOF/TOF plate, and mass spectra of trypsin-digested gel spots were generated on a Biflex III MALDI-TOF (Bruker Daltonik, Gmbh, Bremen, Germany) or Proteome Analyzer 4700 mass spectrometer (Applied Biosystems). MS/MS identification was carried out using Mascot (Matrix Science, London, UK) to search Swiss Prot or MSDB database. Search parameters used were Rodentia (Rodents) as taxonomy, Carbamidomethyl (C) as fixed modification, and Oxidation $(\mathrm{M})$ as variable modification, peptide tolerance at 100 p.p.m., and maximum 1 missed cleavage by trypsin. The criteria used for a positive identification was significant Mowse score. Mowse score $\geq 64$ was considered significant $(P<0.05)$. BioTools (Bruker Daltonik) linked to Matrix Science and those spots that showed statistically significant Mowse score were confirmed by MS/MS for the most abundant peaks from MS.

Differentially abundant proteins were annotated by their GO terms such as biological process, molecular function, and cellular location using Database for Annotation, Visualization and Integrated Discovery (DAVID) Bioinformatics Resources 6.7 (http://david. abcc.ncifcrf.gov/home.jsp).

\section{Total protease activity in UF}

Total protease activity was estimated in rat UF using QuantiCleave protease assay kit (Thermo Scientific, Rockford, IL, USA) as per the manufacturer's instructions. Trypsin, a standard protease, was serially diluted fivefold in the range of $100-0.03 \mu \mathrm{g} / \mathrm{ml}$. Succinylated casein $(2.0 \mathrm{mg} / \mathrm{ml})$ was used as a substrate. UF samples were diluted to $1: 10$ to ensure that the absorbance of the blank (without the substrate) remained below 0.500 . To the wells containing succinylated casein or only assay buffer, $50 \mu \mathrm{l}$ diluted samples or trypsin standards were added. 2,4,6-Trinitrobenzene sulfonic acid was added to each well after incubation for $20 \mathrm{~min}$ at $37^{\circ} \mathrm{C}$. The change in absorbance at $450 \mathrm{~nm}(\Delta \mathrm{A} 450)$, calculated by subtracting the A450 of the blank (sample or standards without substrate) from that of the corresponding casein well, was indicator of the proteolytic activity. A standard curve $(\Delta \mathrm{A} 450$ against trypsin standard 
concentration) was plotted to assess total protease activity of UF samples. Total protease activity was expressed in $\mu \mathrm{g} / \mathrm{mg}$ of UF protein.

\section{Collection of culture supernatants from human endometrial epithelial cell lines}

Two human endometrial epithelial cell lines RL95-2 (CRL-1671) and HEC-1A (HTB-112) were obtained from the American Type Culture Collection (ATCC, Manassas, VA, USA). RL95-2 cell line was maintained in a 1:1 mixture of DMEM (Sigma-Aldrich) and nutrient mixture F-12 containing $15 \mathrm{mM}$ HEPES, L-glutamine, $1.2 \mathrm{~g} / \mathrm{l}$ sodium bicarbonate, and $5.0 \mathrm{mg} / \mathrm{l}$ insulin. HEC$1 \mathrm{~A}$ was grown in McCoy's 5A modified medium (Sigma-Aldrich) with $10 \mathrm{mM}$ HEPES, L-glutamine, and $2.2 \mathrm{~g} / \mathrm{I}$ sodium bicarbonate. To collect the supernatants, cells were grown in media without sera for $24 \mathrm{~h}$. Cell viability was checked by trypan blue exclusion method. Supernatants collected from the cultures having more than 95\% live cells were centrifuged at $135 \mathrm{~g}$ to get rid of cellular contamination. Protein pellets obtained by acetone precipitation of culture supernatants were suspended in $100 \mu \mathrm{l}$ rehydration buffer and stored at $-20{ }^{\circ} \mathrm{C}$ until used.

\section{Western blotting}

Protein samples $(20 \mu \mathrm{g})$ extracted from UF or culture supernatants were resolved on $10 \%$ SDS-PAGE and transferred onto polyvinylidene fluoride membranes (Merck Millipore, Billerica, MA, USA). After blocking, blots were incubated overnight with respective primary antibody (against $\beta$-actin/Rho-GDl $\alpha$ /peroxiredoxins) at $4{ }^{\circ} \mathrm{C}$. $\beta$-Actin antibody (MAB raised in mouse) was procured from Sigma-Aldrich; rabbit MABs to peroxiredoxins ( -2 and -6 ) from Epitomics (Burlingame, CA, USA); and rabbit polyclonal antibody to Rho-GDI $\alpha$ was obtained from Invitrogen (Life Technologies). Antibodies used were cross-reactive to human as well as rat/mouse antigens. After washing with PBST (0.05\% Tween 20 in PBS), blots were incubated for $1 \mathrm{~h}$ with respective secondary antibody (goat anti-rabbit or goat anti-mouse) conjugated to HRP (Dako, Glostrup, Denmark) at room temperature. Immunoreactive bands on the blots were detected using enhanced chemiluminescence (ECL Plus, Amersham Biosciences).

After chemiluminescent detection, blots were stained with Coomassie blue. Intensities of all the bands for each protein sample were determined and summed up using Image Quant (IQTL) software (GE Healthcare Biosciences) to obtain the total intensity, as an indicator of the total protein load. Intensity of the immunoreactive band for the protein of interest on the luminogram was also measured using IQTL software. Ratios of the immunoreactive band intensity to the total protein intensity were compared to calculate the fold change in the abundance of the protein of interest between different conditions.

\section{Immunohistochemical localization}

Uterine sections of $5 \mu \mathrm{m}$ thickness were deparaffinized and rehydrated using descending grades of methanol. Endogenous peroxidase activity was quenched by incubating the uterine sections in $0.3 \% \mathrm{H}_{2} \mathrm{O}_{2}$ for $30 \mathrm{~min}$. This was followed by microwave treatment of the sections for $10 \mathrm{~min}$ in antigen unmasking solution (Vector Laboratories, Burlingame, CA, USA). Sections were blocked with $2 \%$ horse serum (for the sections to be incubated with mouse MABs to $\beta$-actin) or with goat serum (for the sections to be incubated with polyclonal antibodies against peroxiredoxins or Rho-GDla) in PBS for $1 \mathrm{~h}$ at RT. Sections were then incubated with the respective primary antibodies for $16 \mathrm{~h}$ at $4{ }^{\circ} \mathrm{C}$. The negative control sections were incubated with rabbit or mouse IgGs in place of primary antibodies. This was followed by incubations of the sections with biotinylated secondary antibodies raised in either goat or horse (Vector Laboratories) for $1 \mathrm{~h}$ at $37^{\circ} \mathrm{C}$. This was followed by incubation in avidin-biotin-HRP complex for $30 \mathrm{~min}$ followed by the addition of $1 \mathrm{mg} / \mathrm{ml}$ diaminobenzidine (Sigma-Aldrich) prepared in $0.001 \%$ $\mathrm{H}_{2} \mathrm{O}_{2}$ in PBS. Sections were then counterstained with hematoxylin and gradually dehydrated, cleared in xylene, and mounted.

The staining intensities for immunoreactive antigens were determined using the image analysis software Aperio Image scope version v11.2.0.780 (Aperio, Vista, CA, USA). At least ten areas from each section were randomly selected for measuring the integrated optical density (IOD).

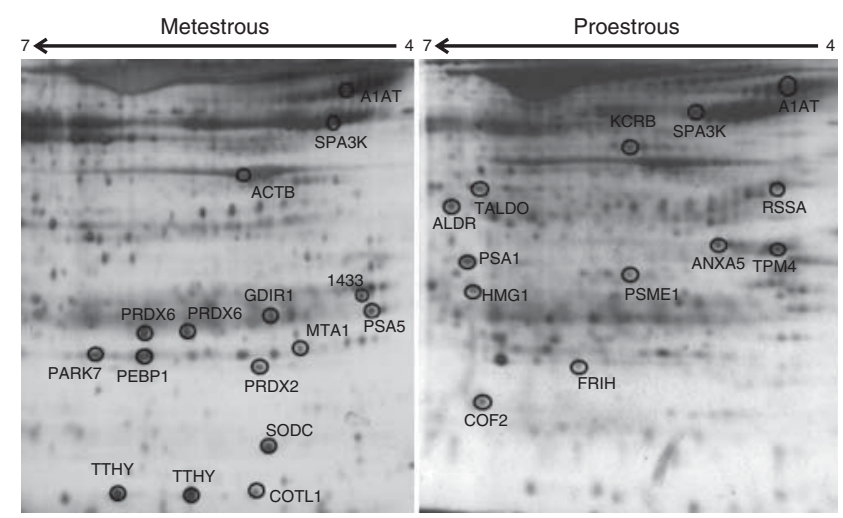

Figure 1 Representative 2D gels of uterine fluid proteins collected in the proestrous and metestrous phases of the estrous cycle. Total protein $(200 \mu \mathrm{g})$ sample was resolved first in the $\mathrm{pH}$ range of 4-7 and then in second dimension on $12 \%$ SDS-PAGE. Circled spots represent those protein spots that were found to be in higher abundance compared with their counterparts in the gel representative of the other phase. These protein spots were identified by MALDI-TOF/TOF or LCMS/MS. 


\section{Statistical analysis}

Nonparametric unpaired Student's t-test was used to determine the significance of difference in the relative levels of immunoreactive antigens on immunoblots and also to evaluate the difference in the intensities of immunolocalized antigens in endometrial tissue sections. This test was also used to determine the difference in total protease activity between proestrous and metestrous groups. The level of statistical significance was selected as $P<0.05$.

\section{Results}

\section{UF proteins displaying differential abundance during the metestrous phase in a nonconception cycle}

Image Master Platinum (IMP) software-assisted analysis of the silver-stained two-dimensional (2D) gels of rat UF collected in the proestrous and metestrous phases of the estrous cycle, revealed the presence of at least 341 and 336 polypeptides respectively (Fig. 1). Two hundred and twenty-six spots were found paired between proestrous and metestrous gels. Comparison of spot volume of paired spots led to the identification of 44 protein spots as differentially abundant by at least twofold. Twentythree proteins were found to be more abundant in metestrous phase while 21 proteins more abundant in proestrous phase fluid, when compared with each other. Differentially abundant protein spots were excised from the gels and trypsin digested. Twenty-nine proteins were identified using matrix-assisted laser desorption/ ionization time-of-flight (MALDI-TOF/TOF) or liquid chromatography-tandem mass spectrometry (LCMS/ MS) with a significant Mowse score (Table 1). Reports of MALDI-TOF/TOF or LCMS/MS analysis are shown as supplementary data.

Table 1 Characteristics of uterine fluid proteins displaying more abundance in the metestrous phase compared with proestrous phase. Proteins were identified by MALDI-TOF/TOF or LCMS/MS. Full-length amino acid sequences of all the proteins were analyzed for the presence of classical and nonclassical signals required for the extracellular secretion using Signal P and Secretome P tools respectively.

\begin{tabular}{|c|c|c|c|c|c|c|c|c|c|}
\hline $\begin{array}{l}\text { Spot } \\
\text { Id }\end{array}$ & Protein identity & $\begin{array}{l}\text { Uniprot } \\
\text { access key }\end{array}$ & $\begin{array}{l}\text { MOWSE } \\
\text { score }\end{array}$ & $\begin{array}{l}\text { Experi- } \\
\text { mental } \\
\text { MW } \\
(\mathrm{kDa})\end{array}$ & $\begin{array}{l}\text { Experi- } \\
\text { mental } \\
\text { pl }\end{array}$ & Known function & $\begin{array}{l}\text { Presence of } \\
\text { classical } \\
\text { signals for } \\
\text { extracellular } \\
\text { secretion }\end{array}$ & $\begin{array}{l}\text { Presence of } \\
\text { nonclassical } \\
\text { signals for } \\
\text { extracellular } \\
\text { secretion }\end{array}$ & $\begin{array}{l}\text { Presence } \\
\text { in human } \\
\text { uterine } \\
\text { fluid }\end{array}$ \\
\hline M1 & Alpha-1-antiprypsin & A1AT_RAT & 90 & $50^{\mathrm{a}}$ & $4.5^{\mathrm{a}}$ & $\begin{array}{l}\text { Inhibitor of serine pro- } \\
\text { teases }\end{array}$ & Yes & Yes & Yes $^{\mathrm{b}, \mathrm{c}}$ \\
\hline M2 & $\begin{array}{l}\text { Contrapsin-like pro- } \\
\text { tease Inhibitor } 1\end{array}$ & SPA3K_RAT & 167 & 46 & $4.7^{\mathrm{a}}$ & $\begin{array}{l}\text { Inhibitor of serine pro- } \\
\text { teases }\end{array}$ & Yes & Yes & - \\
\hline M3 & Actin, cytoplasmic 1 & ACTB_RAT & 641 & 42 & 5.2 & Cellular cytoskeleton & No & No & Yes $^{\mathrm{c}}$ \\
\hline M4 & 14-3-3 Zeta isoform & 1433_RAT & 140 & 27 & 4.7 & $\begin{array}{l}\text { Regulation of signaling } \\
\text { pathway }\end{array}$ & No & No & Yes $^{\mathrm{c}}$ \\
\hline M6 & $\begin{array}{l}\text { Proteasome subunit } \\
\text { alpha type-5 }\end{array}$ & PSA5_RAT & 236 & 26 & 4.6 & $\begin{array}{l}\text { Responsible for the } \\
\text { chymotrypsin-like } \\
\text { activity of the } \\
\text { proteasome }\end{array}$ & No & No & - \\
\hline M8 & $\begin{array}{l}\text { Rho GDP- } \\
\text { dissociation } \\
\text { inhibitor } 1\end{array}$ & GDIR1_RAT & 124 & $26^{\mathrm{a}}$ & 5.1 & $\begin{array}{l}\text { GDP/GTP exchange } \\
\text { reaction of the Rho } \\
\text { proteins }\end{array}$ & No & No & Yes $^{\mathrm{c}}$ \\
\hline M9 & Peroxiredoxin-6 & PRDX6_RAT & 304 & 25 & $5.2^{\mathrm{a}}$ & $\begin{array}{l}\text { Regulation of phospho- } \\
\text { lipid turnover and } \\
\text { protection against } \\
\text { oxidative injury }\end{array}$ & No & No & $\mathrm{Yes}^{\mathrm{c}}$ \\
\hline M10 & Peroxiredoxin-6 & PRDX6_RAT & 187 & 25 & 5.6 & Same as above & No & No & Yes $^{\mathrm{c}}$ \\
\hline M11 & $\begin{array}{l}\text { Phosphatidylethanola- } \\
\text { mine-binding } \\
\text { protein } 1\end{array}$ & PEBP1_RAT & 56 & $22^{\mathrm{a}}$ & 5.4 & $\begin{array}{l}\text { Serine protease } \\
\text { inhibitor }\end{array}$ & No & No & Yes $^{\mathrm{c}}$ \\
\hline M12 & $\begin{array}{l}\text { Contraception-associ- } \\
\text { ated protein } 1\end{array}$ & PARK7_RAT & 114 & $22^{\mathrm{a}}$ & 6.3 & $\begin{array}{l}\text { Sensor for oxidative } \\
\text { stress }\end{array}$ & No & No & - \\
\hline M14 & Peroxiredoxin-2 & PRDX2_RAT & 133 & 22 & 5.4 & $\begin{array}{l}\text { Elimination of } \\
\text { peroxides }\end{array}$ & No & No & Yes $^{\mathrm{c}}$ \\
\hline M16 & $\begin{array}{l}\text { Metastasis-associated } \\
\text { protein MTA-1 }\end{array}$ & MTA1_RAT & 62 & $24^{\mathrm{a}}$ & $5.0^{\mathrm{a}}$ & $\begin{array}{l}\text { Modifies histone } \\
\text { proteins }\end{array}$ & No & No & - \\
\hline M17 & $\begin{array}{l}\text { Rat copper-zinc } \\
\text { containing super } \\
\text { oxide dismutase }\end{array}$ & SODC_RAT & 192 & 16 & $5.3^{\mathrm{a}}$ & $\begin{array}{l}\text { Antioxidant oxido- } \\
\text { reductase }\end{array}$ & No & Yes & - \\
\hline M18 & $\begin{array}{l}\text { Transthyretin chain A } \\
\text { rat }\end{array}$ & TTHY_RAT & 230 & 15 & 5.7 & $\begin{array}{l}\text { Transports thyroid hor- } \\
\text { mone, vitamin A }\end{array}$ & No & Yes & $\mathrm{Yes}^{\mathrm{b}, \mathrm{c}}$ \\
\hline M19 & $\begin{array}{l}\text { Transthyretin chain A } \\
\text { rat }\end{array}$ & TTHY_RAT & 196 & 15 & $6.0^{\mathrm{a}}$ & Same as above & No & Yes & $\mathrm{Yes}^{\mathrm{b}, \mathrm{c}}$ \\
\hline M20 & Coactosin-like protein & COTL1_RAT & 100 & 15 & 5.4 & F-actin binding protein & No & Yes & - \\
\hline
\end{tabular}

${ }^{a}$ Deviation from the theoretical molecular weight $(\mathrm{MW})$ or pl, predicted from the full-length amino acid sequence of the respective protein. These deviations may be attributed to posttranslational modifications. b Hannan et al. (2010). ' Scotchie et al. (2009). 


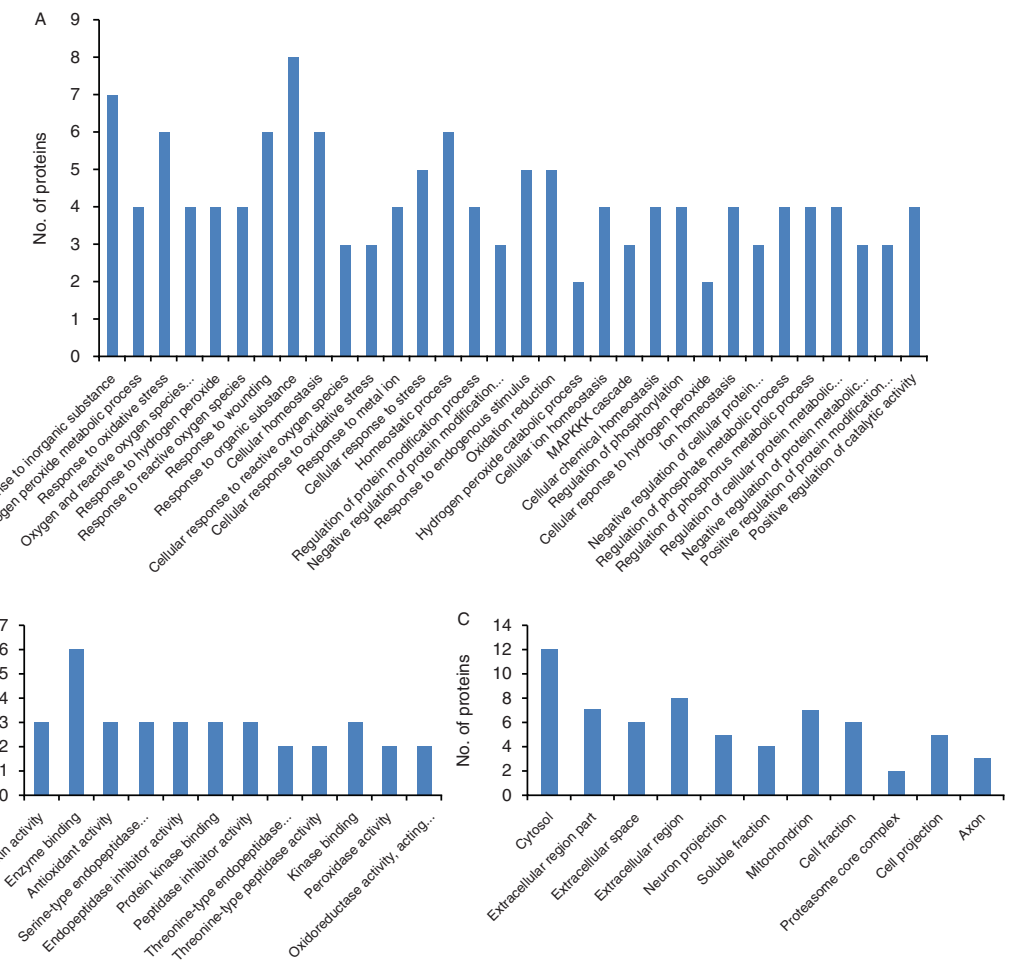

Figure 2 Enrichment of differentially abundant proteins in the Gene Ontology (GO) groups classified based on their molecular function (A), biological process (B), and cellular component (C). Only those groups that had statistically significant $P$ values ( $<0.05$; $t$-test) are shown.
Full-length amino acid sequences of 29 differentially abundant proteins (retrieved from UniProtKB at http:// www.uniprot.org/) were screened for the presence of classical and nonclassical secretory signals using online tools SignalP 4.0 (www.cbs.dtu.dk/services/SignalP/) and SecretomeP 2.0 (www.cbs.dtu.dk/services/Secreto$\mathrm{meP} /$ ) respectively. Of these, alpha 1 antitrypsin and contrapsin-like protease inhibitor 1 had classical signal sequences for the extracellular secretion whereas copper-zinc containing superoxide dismutase, transthyretin, coactosin-like protein, $40 \mathrm{~S}$ ribosomal protein SA, protease activator complex subunit 1 , ferritin, and cofilin 2 were found to have nonclassical signals for the extracellular secretion (Table 1).

Differentially abundant proteins such as alpha-1antitrypsin (A1AT), $\beta$-actin, and peroxiredoxin- 2 and -6 were found to be associated with biological processes such as response to organic or inorganic substances, cellular homeostasis, response to wounding, and response to oxidative stress, as determined using the DAVID database (Fig. 2A). Molecular functions of the differentially abundant proteins such as phosphatidylethanolamine binding protein 1, copper-zinc containing superoxide dismutase, 14-3-3 zeta protein, metastasis-associated protein-1, and peroxiredoxins were enzyme binding, antioxidant activity, and peptidase and endopeptidase activity (Fig. 2B). When categorized based on the cellular component, the majority of differentially abundant proteins were cytosolic or extracellular (Fig. 2C).

\section{UF proteins displaying differential abundance during the embryo attachment stage in a conception cycle}

Analysis of the silver-stained 2D gels of UFs collected from pregnant and pseudopregnant rats on day 4 post coitus (the day of embryo attachment) revealed the presence of at least 364 and 347 polypeptides respectively (Fig. 3). Two hundred and thirty-five spots were
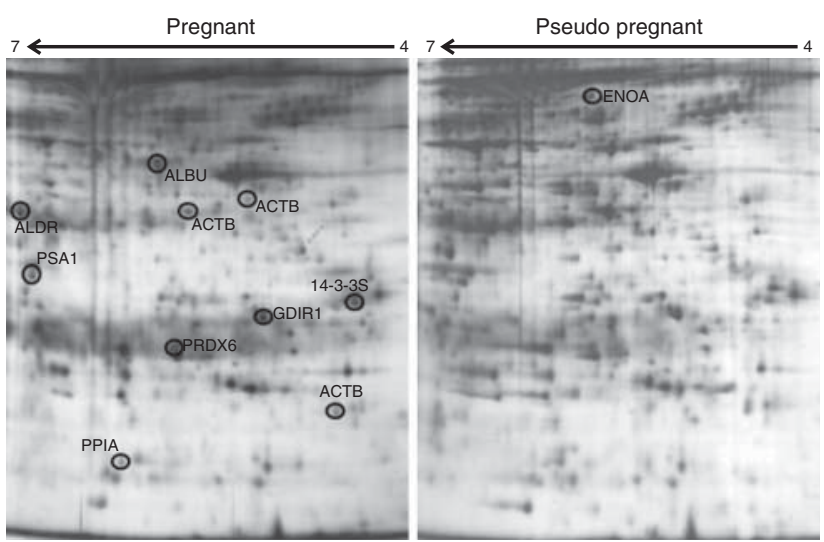

Figure 3 Representative 2D gels of uterine fluid proteins collected from pregnant and pseudopregnant rats on the day 4 post coitus. Proteins $(200 \mu \mathrm{g})$ were resolved in the $\mathrm{pH}$ range of 4-7 and then in the second dimension by $12 \%$ SDS-PAGE. Circled spots represent those protein spots that were more abundant in the pregnant rats compared with pseudopregnant rats. These protein spots were identified by MALDI-TOF/TOF or LCMS/MS. 
found to be paired in the gels representing the UF protein profile of pregnant and pseudopregnant rats. Spot volume comparison of the paired spots led to the identification of 41 protein spots as differentially abundant by at least twofold. Circled spots (Fig. 3) indicate the protein present in higher abundance compared with its counterpart in the other phase. Twenty-one proteins were found to be more abundant in pregnant rats and 20 proteins more abundant in pseudopregnant rats. Excision from the gel and trypsin digestion followed by MALDI-TOF/TOF or LCMS/MS analysis identified 11 proteins with a significant Mowse score (Table 2). Among these, only serum albumin was found to have classical and nonclassical signals for the extracellular secretion. Reports of MALDI-TOF/TOF or LCMS/MS analysis are shown as supplementary data.

\section{Total protease activity in UF}

Total protease activity in the UF was significantly higher $(P<0.05)$ in the proestrous phase, compared with that in the metestrous phase (Fig. 4). Although protease activity was significantly $(P<0.05)$ higher in pregnant animals compared with nonpregnant rats, this did not differ significantly between pregnant and pseudopregnant rats.
Detection of $\beta$-actin, Rho-GDI $\alpha$, and peroxiredoxin-2 and -6 in endometrial epithelial culture supernatants

Immunoblotting of the protein extracts of serumdeprived culture supernatants of two endometrial epithelial cell lines, RL95-2 and HEC1-A, revealed the presence of $\beta$-actin, Rho-specific guanine nucleotide dissociation inhibitor alpha (Rho-GDl $\alpha$ ), and peroxiredoxins (Fig. 5). These results suggested a possibility of these proteins being secreted by the endometrial epithelium in the UF.

\section{Validation of $2 D$ data}

Immunoblotting experiments using specific antibodies were carried out to validate the $2 \mathrm{D}$ data. UF $\beta$-actin was found to be 1.70-fold ( $P=0.0093$ ) and Rho-GDl $\alpha$ to be 2.73-fold $(P=0.0314)$ more abundant in the metestrous phase, compared with that in the proestrous phase (Fig. 6). Peroxiredoxin-2 and peroxiredoxin-6 were also found to be 3.58- $(P=0.006)$ and 2.07 -fold $(P=0.0095)$ respectively more abundant in the metestrous phase (Fig. 6). Thus, immunoblotting results were in concordance with 2D data.

Pregnant and pseudopregnant animals were compared for the abundance of these proteins in the UF.

Table 2 Characteristics of uterine fluid proteins displaying more abundance in the proestrous phase compared with metestrous phase. Proteins were identified by MALDI-TOF/TOF or LCMS/MS. Full-length amino acid sequences of all proteins were analyzed for the presence of classical and nonclassical signals required for extracellular secretion using Signal P and Secretome P tools respectively.

\begin{tabular}{|c|c|c|c|c|c|c|c|c|c|}
\hline $\begin{array}{l}\text { Spot } \\
\text { Id }\end{array}$ & Protein identity & $\begin{array}{l}\text { Uniprot } \\
\text { access key }\end{array}$ & $\begin{array}{l}\text { MOWSE } \\
\text { score }\end{array}$ & $\begin{array}{c}\text { Experi- } \\
\text { mental } \\
\mathrm{MW}(\mathrm{kDa})\end{array}$ & $\begin{array}{c}\text { Experi- } \\
\text { mental pl }\end{array}$ & Known function & $\begin{array}{c}\text { Presence } \\
\text { of classi- } \\
\text { cal signals } \\
\text { for extra- } \\
\text { cellular } \\
\text { secretion }\end{array}$ & $\begin{array}{c}\text { Presence of } \\
\text { nonclassi- } \\
\text { cal signals } \\
\text { for extra- } \\
\text { cellular } \\
\text { secretion }\end{array}$ & $\begin{array}{c}\text { Presence } \\
\text { in human } \\
\text { uterine } \\
\text { fluid }\end{array}$ \\
\hline P1 & $\begin{array}{l}\text { Contrapsin-like } \\
\text { protease inhibitor } 1\end{array}$ & SPA3K_RAT & 360 & 46 & $5.3^{\mathrm{a}}$ & $\begin{array}{l}\text { Inhibitor of serine } \\
\text { proteases }\end{array}$ & Yes & Yes & - \\
\hline P2 & Anti-trypsin precursor & A1AT_RAT & 356 & 46 & $4.9^{\mathrm{a}}$ & $\begin{array}{l}\text { Inhibitor of serine } \\
\text { proteases }\end{array}$ & Yes & Yes & - \\
\hline P3 & $\begin{array}{l}\text { Creatine kinase, } \\
\text { B chain }\end{array}$ & KCRB_RAT & 436 & 43 & 5.3 & Energy transduction & No & No & Yes $^{b, c}$ \\
\hline P4 & Transaldolase & TALDO_RAT & 166 & 38 & 6.6 & Pentose metabolism & No & No & - \\
\hline P5 & Aldose reductase & ALDR_RAT & 239 & 36 & $6.8^{\mathrm{d}}$ & $\begin{array}{l}\text { Catalysis of NADPH- } \\
\text { dependent } \\
\text { reduction }\end{array}$ & No & No & - \\
\hline P6 & $\begin{array}{l}40 \mathrm{~S} \text { ribosomal } \\
\text { protein SA }\end{array}$ & RSSA_RAT & 233 & 38 & 4.8 & Signaling pathways & No & Yes & - \\
\hline P8 & $\begin{array}{l}\text { Tropomyosin alpha- } 4 \\
\text { chain }\end{array}$ & TPM4_RAT & 338 & $32^{\mathrm{d}}$ & 4.8 & $\begin{array}{r}\text { Regulation of smooth } \\
\text { muscle contraction }\end{array}$ & No & No & $\mathrm{Yes}^{\mathrm{c}}$ \\
\hline P9 & $\begin{array}{l}\text { Annexin V (Lipocortin } \\
\mathrm{V})\end{array}$ & ANXA5_RAT & 514 & 36 & 4.9 & $\begin{array}{l}\text { Positive regulation of } \\
\text { apoptosis }\end{array}$ & No & No & Yes $^{\mathrm{c}}$ \\
\hline P12 & $\begin{array}{l}\text { Protease activator } \\
\quad \text { complex subunit } 1\end{array}$ & PSME1_RAT & 269 & 29 & $5.77^{d}$ & $\begin{array}{l}\text { Degradation of incor- } \\
\text { rectly folded } \\
\text { proteins }\end{array}$ & No & Yes & - \\
\hline P14 & $\begin{array}{l}\text { Proteosome subunit } \\
\text { alpha type } 1\end{array}$ & PSA1_RAT & 96 & 30 & $6.6^{\mathrm{d}}$ & Same as above & No & No & - \\
\hline P15 & $\begin{array}{l}\text { High-mobility group } \\
\text { protein B1 }\end{array}$ & HMG1_RAT & 190 & 25 & $6.6^{\mathrm{d}}$ & $\begin{array}{l}\text { Histone binding } \\
\text { protein }\end{array}$ & No & No & - \\
\hline P20 & Ferritin heavy chain & FRIH_RAT & 74 & 21 & 5.8 & Ferroxidase activity & No & Yes & - \\
\hline P21 & Cofilin-2 & COF2_MUS & 73 & 18 & $6.6^{\mathrm{d}}$ & Actin reorganization & No & Yes & - \\
\hline
\end{tabular}

${ }^{\mathrm{a}} \mathrm{A}$ different isoform of the same protein reported in Table 1. ${ }^{\mathrm{b}}$ Hannan et al. (2010). ${ }^{\mathrm{c}}$ Scotchie et al. (2009). ${ }^{\mathrm{d}}$ Deviation from the theoretical molecular weight $(\mathrm{MW})$ or pl, predicted from the full-length amino acid sequence of the respective protein. These deviations could be attributed to posttranslational modifications. 

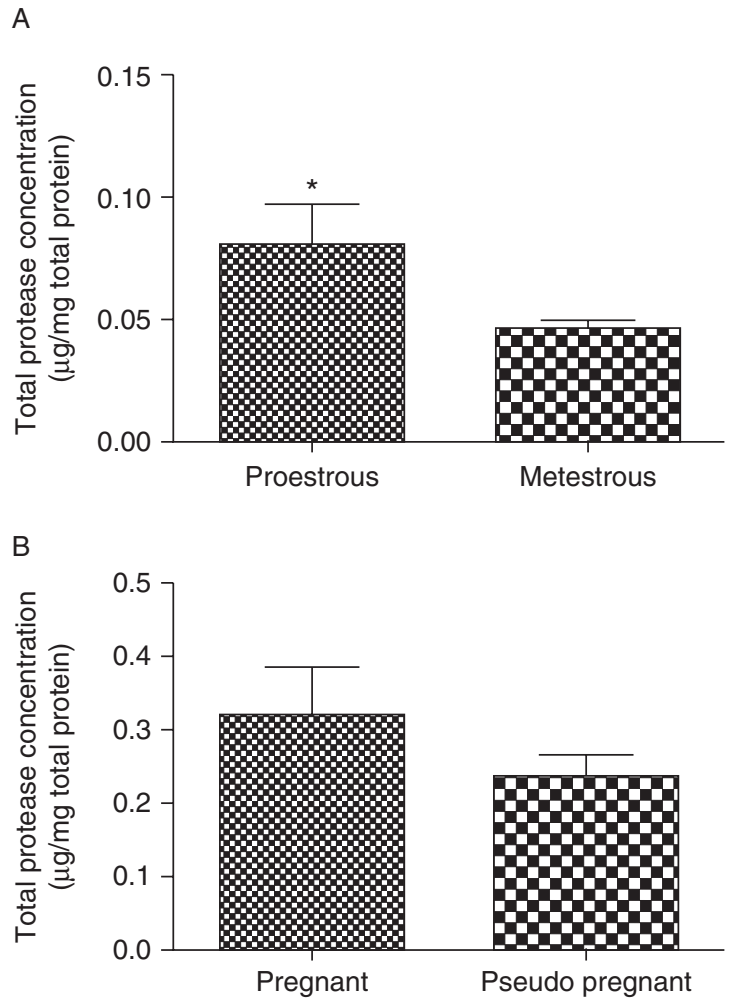

Figure 4 Estimation of total protease activity in the uterine fluid (UF) samples collected from the nonpregnant rats in their proestrous and metestrous phases (A) and also in the samples collected from the pregnant and pseudopregnant rats on day 4 post coitus (B). Total protease activity was expressed as $\mu \mathrm{g} / \mathrm{mg}$ protein recovered from the UF. ${ }^{*} P<0.05$, where $P$ is the level of significance of the difference (by $t$-test).

$\beta$-Actin was 3.01 -fold $(P=0.0002)$ and Rho-GDl $\alpha$ was 1.64 -fold $(P=0.02)$ more abundant in the pregnant rats, compared with the pseudopregnant rats (Fig. 7).

Peroxiredoxin- 6 was 1.4-fold more abundant in the UF of pregnant rats, compared with that in the pseudopregnant rats (Fig. 7). Whereas, no significant change was found in the abundance of peroxiredoxin-2 in the UF of pregnant and pseudopregnant rats.

\section{Detection of $\beta$-actin, Rho-GDI $\alpha$, and peroxiredoxin-2 and -6 in the endometrial tissues}

$\beta$-Actin, Rho-GDl $\alpha$, and peroxiredoxin- 2 and -6 were localized in the glands as well as in the stroma of rat endometrium. Their localization was found to be more intense in the glandular epithelium compared with that in the stroma (Fig. 8A). Semiquantitative analysis of the intensities of immunoreactive antigens in the endometrial tissues demonstrated significantly $(P<0.05)$ higher expression of $\beta$-actin, Rho-GDl $\alpha$, and peroxiredoxins in the metestrous phase (Fig. 8A, a, b, c, and d) compared with that in the proestrous phase (Fig. $8 \mathrm{~A}, \mathrm{e}, \mathrm{f}, \mathrm{g}$, and $\mathrm{h}$ and Supplementary Figure S1, see section on supplementary data given at the end of this article). This was similar to the pattern detected in the UF samples, collected in proestrous and metestrous phases. These proteins could also be localized in the luminal epithelial compartment of endometrium. Intensities of the immunoreactive proteins appeared higher in the metestrous phase, than in the proestrous phase endometrium (Fig. 8D). This was suggestive of the possibility that the endometrial epithelium could be one of the sources from which these proteins are secreted into the uterine lumen.

Pregnant animals also demonstrated significantly higher intensities of endometrial $\beta$-actin, Rho-GDl $\alpha$, and peroxiredoxins compared with pseudopregnant animals (Fig. 9 and Supplementary Figure S2).

\section{Discussion}

The uterine lining (i.e. endometrium) acquires competency for embryo attachment during the receptive phase in a menstrual cycle. It also assumes a secretory phenotype (Denker 1994). Uterine secretions contribute toward creating an optimal milieu for embryonic growth, development, and attachment. The majority of evidence for this notion originated from studies in animal models. Restriction of embryos to the oviduct, by ligation of the tubo-uterine junction, led to a halt in their development at the early blastocyst stage (Kirby 1962). Embryos remained unattached or became degenerated in the uterine cavity of pregnant ewes, whose uteri lacked endometrial epithelial glands and their secretions (Gray et al. 2002). In humans also, infertility in some cases was found to be associated with altered levels of proteins such as leukemia inhibitory factor, proprotein convertase, and mucin-1 in the UF (Aplin et al. 1996, Mikolajczyk et al. 2006, Heng et al. 2011). Thus, investigations of the UF in the receptive phase assume significance as these may lead to the identification of the biomarkers of endometrial function. In addition,

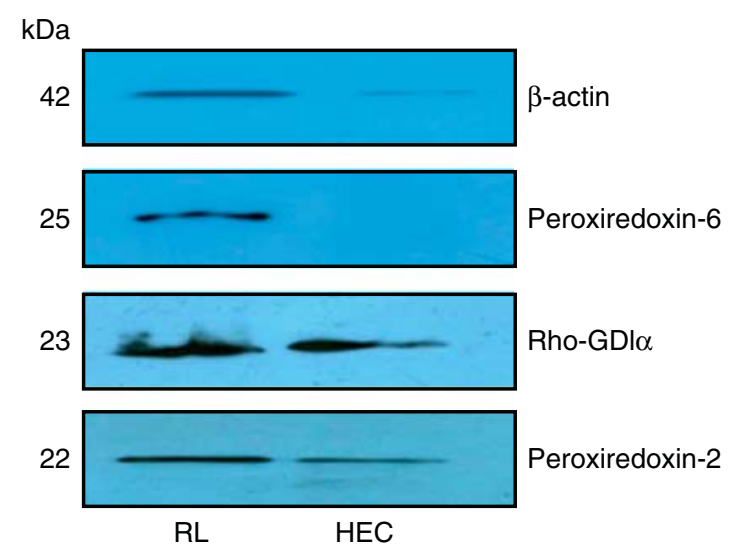

Figure 5 Detection of $\beta$-actin, peroxiredoxins, and Rho-GDl $\alpha$ in the culture supernatants of human endometrial epithelial cell lines, RL95-2 and HEC1-A. Protein samples precipitated from the culture supernatants of cell lines were immunoprobed with the respective antibodies. 
A

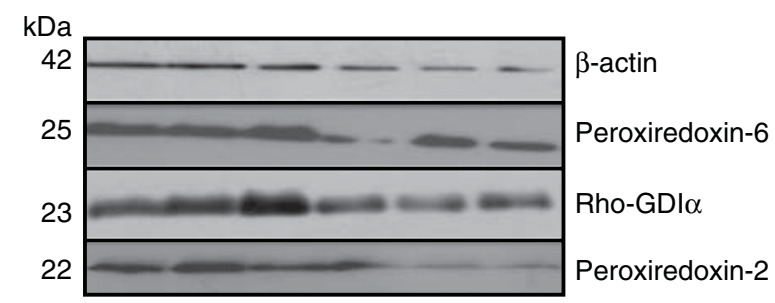

B

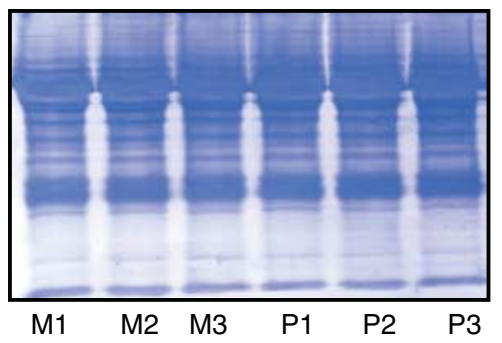

C

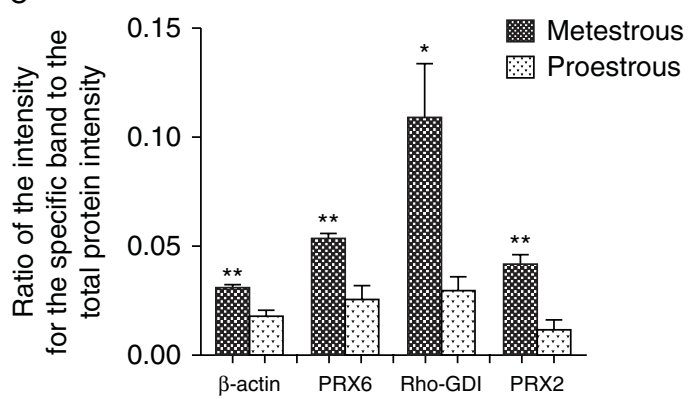

Figure 6 Immunodetection to compare the levels of $\beta$-actin, Rho-GDI $\alpha$, and peroxiredoxin- 2 and -6 in the metestrous and proestrous uterine fluid (UF). M1, M2, and M3 and P1, P2, and P3 represent the protein extracts of UF samples collected from three individual animals in metestrous $(\mathrm{M})$ or proestrous phase $(\mathrm{P})$ respectively. UF proteins were resolved by SDS-PAGE and blotted onto a nylon membrane. Blots were immunoprobed with respective antibodies and immunoreactive antigens were detected by ECL (A). The density of the band corresponding to the respective immunoreactive antigen on the luminogram was measured using Image Quant software (IQTL). After immunoprobing, the blots were stained with Coomassie blue to determine the total protein load in each lane (B). Total protein intensity of each sample was measured by summation of all the protein bands using IQTL. The ratio of the intensity of the immunoreactive band for the protein of interest to total protein intensity was calculated for each sample (C). Mean ratios ( \pm s.D.) were calculated for each group. Significance of the difference between mean ratios for proestrous and metestrous groups was calculated by Student's $t$-test. $* P<0.05$, ${ }^{* *} P<0.01$, where $P$ is the level of significance of the difference.

proteomic analysis of the UF, collected before or during embryo attachment, may provide significant insights into the uterine milieu that favours embryo implantation.

The present study demonstrated differential abundance of 44 UF proteins in the metestrous or receptive phase, compared with the proestrous phase. This indirectly suggested hormone-dependent modulation in the UF protein repertoire during a nonconception cycle. When categorized according to the 'molecular function', the majority of differentially abundant proteins (e.g. A1AT, contrapsin-like protease inhibitor, proteasome subunit alpha 5, and phosphatidylethanolamine binding protein-1) were enriched in the groups typified by serine or threonine-type endopeptidase activity and peptidase inhibitor activity. Previous reports have also demonstrated the presence of proteases in the UF of rats, mice, and rabbits (Joshi et al. 1970, Beier 1974, Hoversland \& Weitlauf 1982). Our 2D data

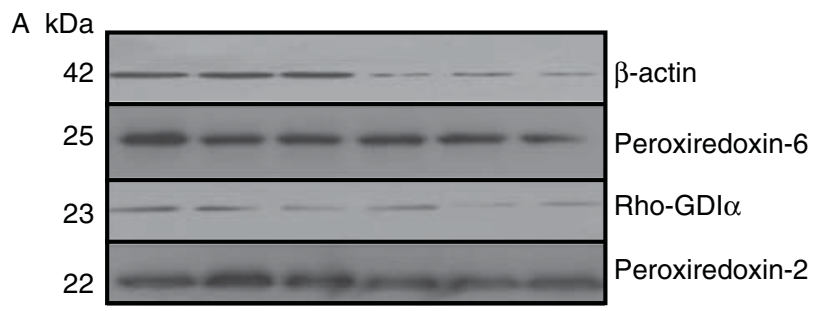

B

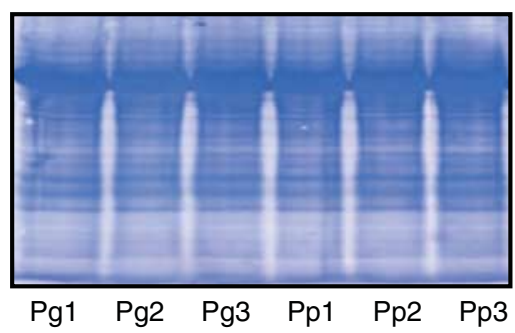

C

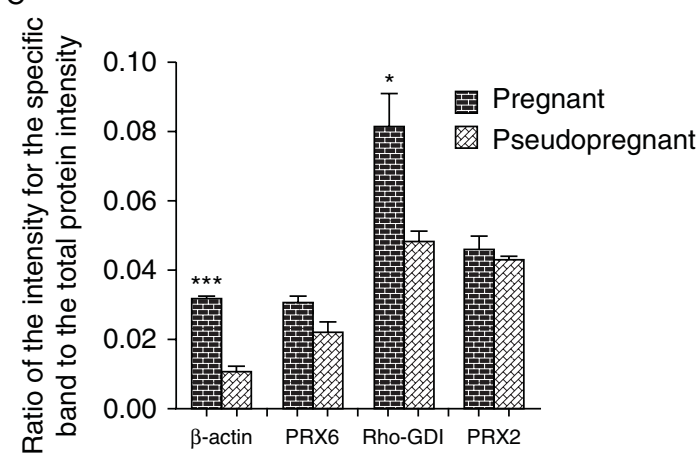

Figure 7 Immunodetection to compare the levels of $\beta$-actin, Rho-GDl $\alpha$, and peroxiredoxins in the uterine fluid (UF) samples collected from pregnant (Pg) and pseudopregnant (Pp) rats on day 4 post coitus. Pg1, $\mathrm{Pg} 2$, and Pg3 and Pp1, Pp2, and Pp3 represent the protein extracts of UF samples collected from three individual pregnant (Pg) and pseudopregnant $(\mathrm{Pp})$ animals. UF proteins were resolved by SDS-PAGE and blotted onto nylon membrane. Blots were immunoprobed with respective antibodies and the immunoreactive antigens were detected by ECL (A). The density of the band corresponding to the respective immunoreactive antigen on the luminogram was measured using Image Quant (IQTL) software. After immunoprobing, the blots were stained with Coomassie blue to determine the total protein load in each lane (B). Total protein intensity for each sample was measured by summation of all the bands using IQTL. The ratio of the intensity of the immunoreactive band for the protein of interest to total protein intensity was calculated for each sample (C). Mean ratios ( \pm s.D.) were calculated for each group. Significance of the difference in the mean ratios between pregnant and pseudopregnant groups was calculated by Student's $t$-test. ${ }^{*} P<0.05,{ }^{* * *} P<0.001$, where $P$ is the level of significance of the difference. 
A
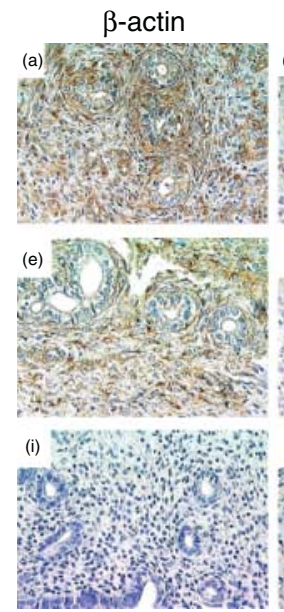

Rho-GDl $\alpha$
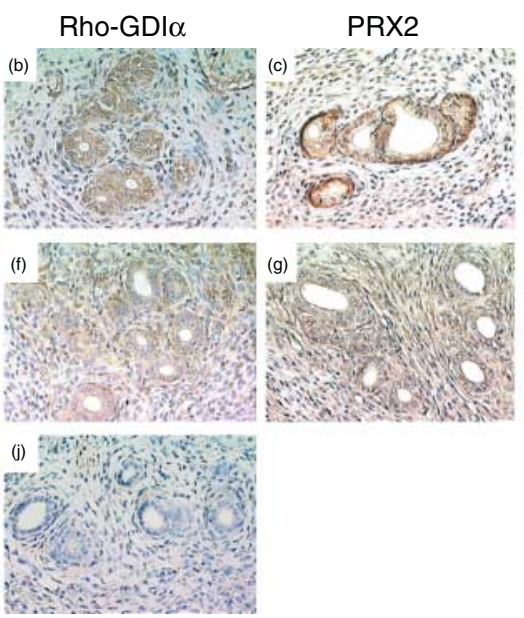
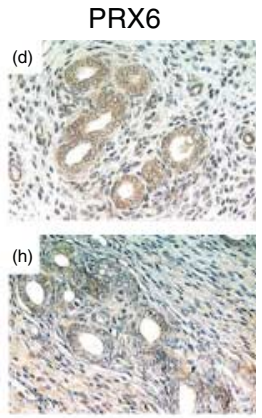

$\mathrm{B}$

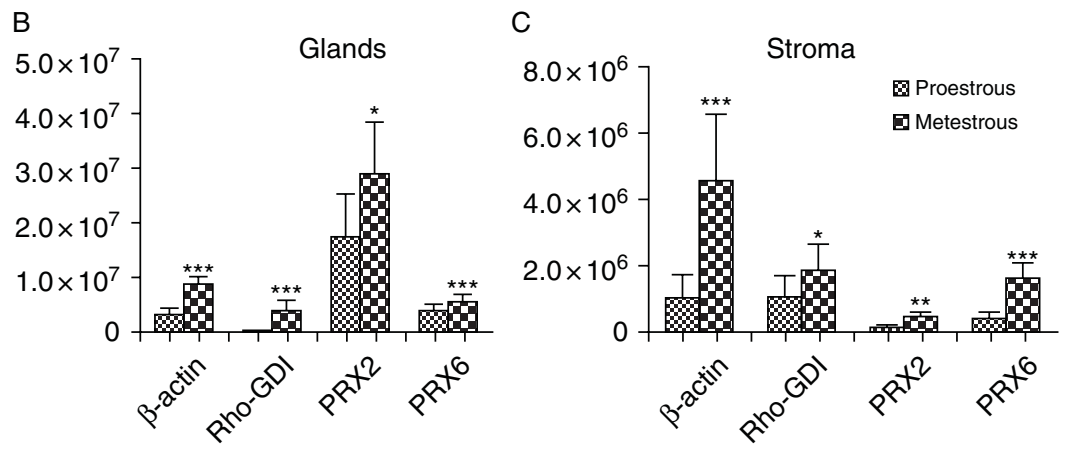

D
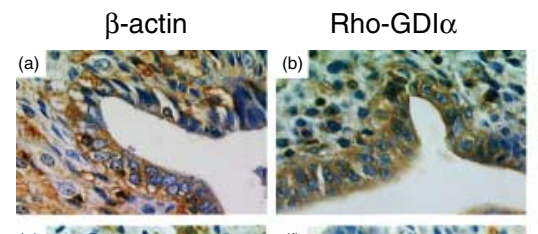

Rho-GDlo
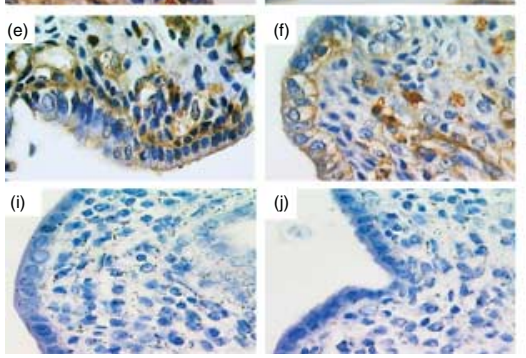

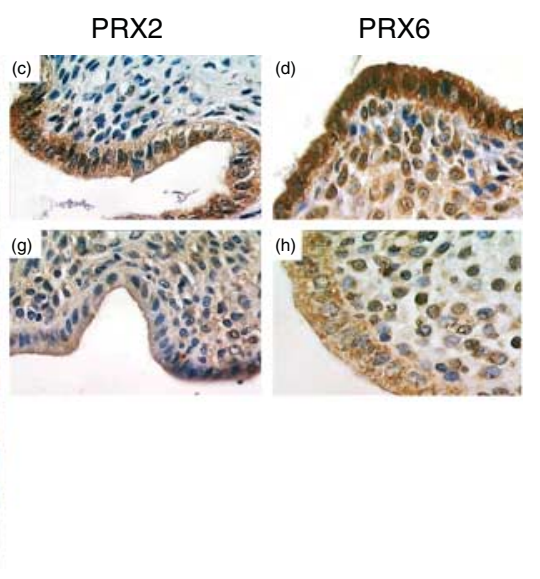

Figure 8 (A) Immunohistochemical localization of $\beta$-actin (a and e), Rho-GDl $\alpha$ (b and $f$ ), peroxiredoxin-2 (c and g), and peroxiredoxin- 6 ( $\mathrm{d}$ and $\mathrm{h}$ ) in the metestrous (a, b, c, and d) and proestrous (e, $f, g$, and $h$ ) phase endometrial tissues. Panels $i$ and $j$ represent the sections where primary antibodies were replaced with rabbit and mouse IgGs respectively. Magnification $40 \times$. Panels B and C display results of the semiquantitative analysis of the intensities of immunoreactive antigens in glandular epithelial or stromal compartments respectively. ${ }^{*} P$ value $<0.05$, ${ }^{* *} P$ value $<0.001,{ }^{* * *} P$ value $<0.0001$ ( $t$-test). Panel $D$ shows immunolocalization of $\beta$-actin (a and e), Rho-GDI $\alpha$ (b and f), peroxiredoxin-2 (c and g), and peroxiredoxin-6 ( $\mathrm{d}$ and $\mathrm{h}$ ) in the luminal epithelial compartments of metestrous (a, b, c, and d) and proestrous (e, f, g, and h) phase endometrial tissues. Panels $i$ and $j$ represent negative control sections where primary antibodies were replaced with rabbit and mouse IgGs respectively. Magnification $100 \times$. demonstrated hormone-dependent modulation in the abundance of proteases as well as protease inhibitors in the UF. This was further supported by detection of significantly higher total protease activity in the proestrous phase, compared with that in the metestrous phase. Regulation of the UF protease activity probably ensures the survival of embryos in the uterine cavity as well as their invasion into the endometrium.

Interestingly different isoforms of A1AT precursor and contrapsin-associated protein showed differential abundance in the proestrous and metestrous phases of a nonconception cycle. In humans also, different isoforms of A1AT were overrepresented in different phases of the menstrual cycle (Parmar et al. 2008, Scotchie et al. 2009). This raises the possibility that in different hormonal milieu, different isoforms of a protein are expressed.

For validation of $2 \mathrm{D}$ data, we focused on four proteins - $\beta$-actin, Rho-GDl $\alpha$, and peroxiredoxin-2 and -6, annotated as cytosolic proteins by Gene Ontology (GO) analysis on the basis of cellular component. It was intriguing to detect the presence of cytosolic proteins in the UF. Although others have also reported the presence of cytosolic proteins such as tubulin and 
A
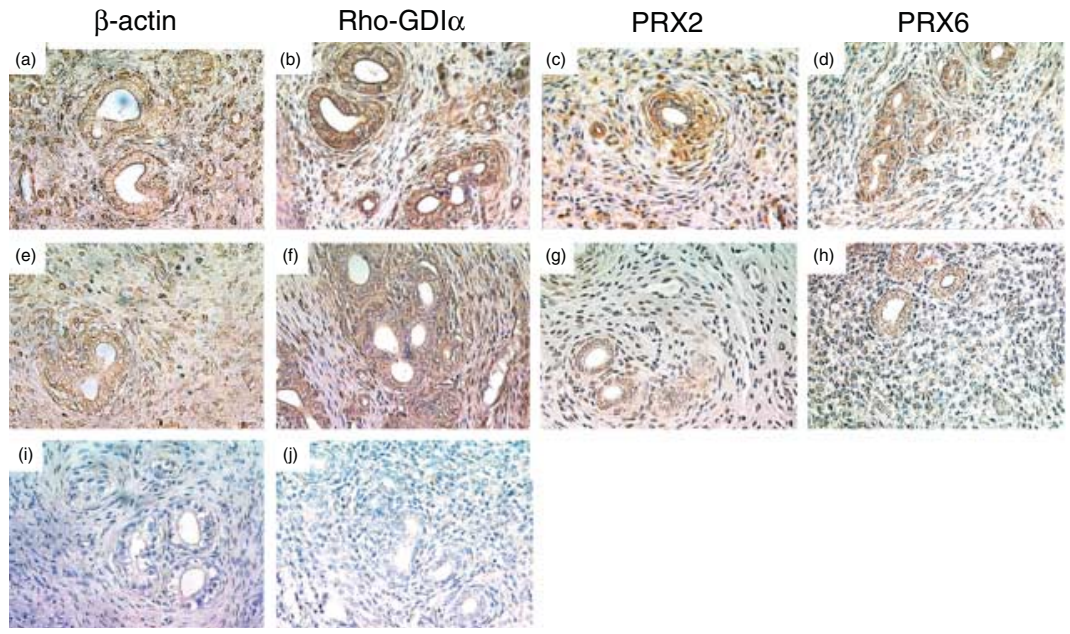

B

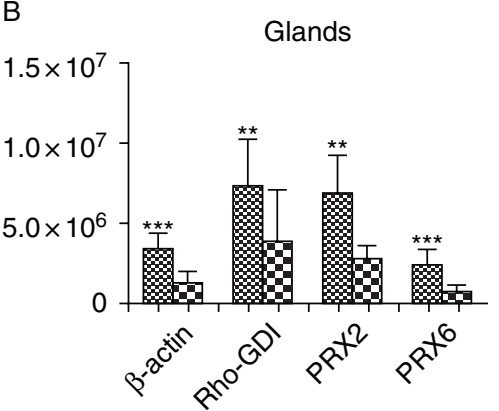

C

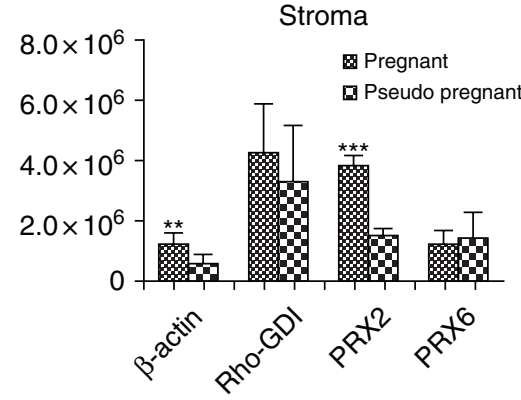

Figure 9 (A) Immunohistochemical localization of $\beta$-actin ( $a$ and $e)$, Rho-GDl $\alpha$ ( $b$ and $f$ ), peroxiredoxin-2 (c and g), and peroxiredoxin- 6 ( $\mathrm{d}$ and $\mathrm{h}$ ) in the pregnant $(\mathrm{a}, \mathrm{b}, \mathrm{c}$, and $\mathrm{d})$ and pseudopregnant (e, f, g, and h) rat endometrial tissues. Panels i and j represent the sections where primary antibodies were replaced with rabbit and mouse IgGs respectively. Magnification $40 \times$. Panels B and C display results of the semiquantitative analysis of the intensities of immunoreactive antigens in glandular epithelial and stromal compartments respectively. ${ }^{* *} P$ value $<0.001,{ }^{* * *} P$ value $<0.0001$ ( $t$-test). cofilin in the endometrial secretome (Scotchie et al. 2009), these are not considered as conventional secretory proteins. When analyzed in silico, these proteins were found to have no signals (classical and/or nonclassical) for extracellular secretion. The presence of these proteins in the UF can be attributed to two possibilities. One possibility was that these proteins may find their way into the UF because of the contamination with endometrial cells and their subsequent rupture during sample collection. We ruled out this possibility by immediately centrifuging the samples after collection to get rid of a cellular contamination. The other possibility was that these proteins in the UF indeed represent a physiological event and are released into the uterine cavity through extracellular secretion or cellular apoptosis. It has been reported that the endometrial epithelium undergoes apoptosis during the receptive phase in rodents (Parr et al. 1987). There is another possibility that some proteins (including those which lack classical secretory signals) are released into the UF by an apocrine mode, which involves release of secretory vesicles, along with some cytoplasmic contents into the lumen. Indeed, scanning electron microscopy-based evidence exists which indicates that endometrial secretion occurs via an apocrine mode (Hafez et al. 1975, 1977). Detection of these proteins in the culture supernatants of human endometrial epithelial cell lines strengthens the possibility of their in vivo secretion by the endometrial epithelium. It will be interesting to investigate whether $\beta$-actin, Rho-GDl $\alpha$, and other UF proteins execute their conventional functions (for example, $\beta$-actin-mediated cytoskeleton arrangement) or they assume novel functions in an extracellular milieu.

Levels of specific proteins in the UF may vary either because of differential secretion into the luminal cavity or due to differential synthesis by the endometrium. We observed relatively higher expression of endometrial $\beta$-actin, Rho-GDla, and peroxiredoxins in the metestrous phase, compared with that in the proestrous phase. Pregnant rats also demonstrated higher expression of endometrial $\beta$-actin, Rho-GDl $\alpha$, and peroxiredoxins compared with pseudopregnant rats. The expression patterns of these proteins in the endometrial tissues were similar to those found in the UF, when compared between pregnancy and pseudopregnancy or between proestrous and metestrous phases. Thus, an increased abundance of these proteins in the UF may be attributed to an increased synthesis in the endometrial epithelium, during the receptive phase in a nonconception cycle and also during pregnancy. These proteins were found to be localized in the luminal epithelium of endometrium, thereby strengthening the possibility of their secretion from the endometrium into the uterine cavity. 
Table 3 Characteristics of proteins displaying differential abundance in the uterine fluid of pregnant and pseudopregnant animals. Proteins were identified by MALDI-TOF/TOF or LCMS/MS. Full-length amino acid sequences of all proteins were analyzed for the presence of classical and nonclassical signals for extracellular secretion.

\begin{tabular}{|c|c|c|c|c|c|c|c|c|c|c|}
\hline Spot Id & $\begin{array}{l}\text { Protein } \\
\text { identity }\end{array}$ & $\begin{array}{l}\text { Uniprot } \\
\text { access key }\end{array}$ & $\begin{array}{c}\text { MOWSE } \\
\text { score }\end{array}$ & $\begin{array}{c}\text { Experi- } \\
\text { mental } \\
\text { MW } \\
(\mathrm{kDa}) \\
\end{array}$ & $\begin{array}{c}\text { Experi- } \\
\text { mental pl }\end{array}$ & $\begin{array}{l}\text { Higher } \\
\text { abun- } \\
\text { dance }\end{array}$ & $\begin{array}{l}\text { Known } \\
\text { function }\end{array}$ & $\begin{array}{l}\text { Presence } \\
\text { of classi- } \\
\text { cal signals } \\
\text { for extra- } \\
\text { cellular } \\
\text { secretion }\end{array}$ & $\begin{array}{l}\text { Presence } \\
\text { of non- } \\
\text { classical } \\
\text { signals for } \\
\text { extra- } \\
\text { cellular } \\
\text { secretion }\end{array}$ & $\begin{array}{l}\text { Presence } \\
\text { in human } \\
\text { uterine } \\
\text { fluid }\end{array}$ \\
\hline SB22 & Serum albumin & ALBU_RAT & 322 & $46^{\mathrm{a}}$ & $5.8^{\mathrm{a}}$ & Pregnant & $\begin{array}{l}\text { Regulation of } \\
\text { the colloidal } \\
\text { osmotic } \\
\text { pressure of } \\
\text { blood and } \\
\text { transporter } \\
\text { protein }\end{array}$ & Yes & Yes & - \\
\hline SB26 & $\begin{array}{l}\text { Aldose } \\
\text { reductase }\end{array}$ & ALDR_RAT & 179 & 36 & $6.8^{\mathrm{a}}$ & Pregnant & $\begin{array}{l}\text { Converts glu- } \\
\text { cose into } \\
\text { fructose }\end{array}$ & No & No & - \\
\hline SB23 & $\begin{array}{l}\text { Actin, cyto- } \\
\text { plasmic } 1\end{array}$ & ACTB_RAT & 359 & $40^{\mathrm{a}}$ & 5.2 & Pregnant & $\begin{array}{l}\text { Cytoskeleton } \\
\text { protein }\end{array}$ & No & No & $Y_{e s}^{b, c}$ \\
\hline SB24 & $\begin{array}{l}\text { Actin, cyto- } \\
\text { plasmic } 1\end{array}$ & ACTB_RAT & 87 & $38^{\mathrm{a}}$ & $5.6^{\mathrm{a}}$ & Pregnant & Same as above & No & No & $Y_{e s}^{c}$ \\
\hline SB27 & $\begin{array}{l}\text { Proteosome } \\
\text { subunit } \\
\text { alpha, type } 1\end{array}$ & PSA1_RAT & 84 & 30 & $6.6^{\mathrm{a}}$ & Pregnant & $\begin{array}{l}\text { ATP-dependent } \\
\text { proteolytic } \\
\text { activity }\end{array}$ & No & No & - \\
\hline SB31 & $\begin{array}{l}\text { 14-3-3 sigma } \\
\text { protein }\end{array}$ & 1433S_MOUSE & 108 & 30 & 4.7 & Pregnant & $\begin{array}{l}\text { Signaling } \\
\text { pathways }\end{array}$ & No & No & $Y_{e s}^{c}$ \\
\hline SB32 & $\begin{array}{l}\text { Rho GDP-dis- } \\
\text { sociation } \\
\text { inhibitor } 1\end{array}$ & GDIR1_RAT & 110 & $26^{a}$ & 5.1 & Pregnant & $\begin{array}{l}\text { GDP/GTP } \\
\text { exchange } \\
\text { reaction of } \\
\text { the Rho } \\
\text { proteins }\end{array}$ & No & No & $Y_{e s}{ }^{c}$ \\
\hline SB34 & Peroxiredoxin-6 & PRDX6_RAT & 184 & 25 & 5.6 & Pregnant & $\begin{array}{l}\text { Regulation of } \\
\text { phospholi- } \\
\text { pid turnover } \\
\text { and protec- } \\
\text { tion against } \\
\text { oxidative } \\
\text { injury }\end{array}$ & No & No & Yes $^{c}$ \\
\hline SB36 & Actin & ACTB_RAT & 103 & $20^{\mathrm{a}}$ & $4.3^{\mathrm{a}}$ & Pregnant & $\begin{array}{l}\text { Cytoskeleton } \\
\text { protein }\end{array}$ & No & No & $Y_{e s}^{c}$ \\
\hline SB40 & $\begin{array}{l}\text { Peptidylpoly- } \\
\text { cistrans } \\
\text { isomerase }\end{array}$ & PPIA_RAT & 70 & 17 & $5.8^{\mathrm{a}}$ & Pregnant & $\begin{array}{l}\text { Folding of } \\
\text { proteins }\end{array}$ & No & No & - \\
\hline SB1 & Alpha enolase & ENOA_RAT & 102 & $58^{\mathrm{a}}$ & $5.6^{\mathrm{a}}$ & $\begin{array}{l}\text { Pseudo- } \\
\text { preg- } \\
\text { nant }\end{array}$ & $\begin{array}{l}\text { Receptor and } \\
\text { activator of } \\
\text { plasminogen } \\
\text { and stimu- } \\
\text { lates immu- } \\
\text { noglobulin } \\
\text { production }\end{array}$ & No & No & - \\
\hline
\end{tabular}

${ }^{a}$ Deviation from the theoretical molecular weight (MW) or pl, predicted from the full-length amino acid sequence of the respective protein. These deviations may arise due to posttranslational modifications. ${ }^{\prime}$ Hannan et al. (2010). ${ }^{\mathrm{c}}$ Scotchie et al. (2009).

Interestingly, in humans also, expression of endometrial $\beta$-actin has been reported to be upregulated in the receptive phase (Chen et al. 2009). In the same study, expression of endometrial Rho-GDl $\alpha$ was also found to be higher in the receptive phase. Rho-GDI are negative regulators of Rho family GTPases, which control various processes, including cell adhesion, migration, proliferation, and actin-dependent cytoskeletal morphogenesis (Hall \& Nobes 2000). Our investigation of the rat UF revealed the same pattern, i.e. higher levels of Rho-GDI $\alpha$ in the receptive phase compared with the proestrous phase. Thus, the pattern of cycle-dependent abundance, at least for some proteins, in UF was found to be akin to that in endometrium. This reinforces the utility of UF analysis in assessing the endometrial function.

Peroxiredoxins in the UF were found to be more abundant in the metestrous phase, compared with the proestrous phase, in nonpregnant rats. Peroxiredoxins are known to play an important role in protection against oxidative injury (Immenschuh \& Baumgart-Vogt 2005). It is well established that embryo metabolism results in reactive oxygen species, excess of which can 
induce development block and retardation of embryonic growth (Guerin et al. 2001). Increased levels of peroxiredoxins in the UF probably protect the embryo from oxidative injury.

We scanned available proteomic data on the human UF to investigate whether rodents and humans share any similarity in terms of their UF protein repertoire and hormonal modulation. Eleven proteins, including $\beta$-actin and A1AT precursor, have been reported in the human UF also (Table 3 ). As observed in rats, $\beta$-actin levels in the human UF were higher and those of tropomyosin $\alpha 4$ chain, lower in the receptive phase, compared with the pre-receptive phase. Thus, to some extent, receptivity-associated events appear to be conserved in rats and humans.

Uterine luminal fluid samples of sheep, cattle, and pigs have been previously investigated to define adaptation in the uterine microenvironment in response to the presence of the conceptus (Bazer et al. 2012). In the present study, gestational UF, collected at the time of embryo attachment, was investigated for its protein complement. Results indicated a differential abundance of 41 proteins in the UF of pregnant animals, compared with pseudopregnant animals. These proteins could have been secreted by either the embryo or the endometrium in response to embryonic signals or by both.

$2 \mathrm{D}$ as well as immunoblotting data demonstrated higher levels of $\beta$-actin in the UF of pregnant animals, compared with pseudopregnant animals. The presence of $\beta$-actin has also been reported in the sheep UF during initial embryo attachment (Lee et al. 1998). In the present study, different forms of $\beta$-actin were detected in the $2 \mathrm{D}$ gels representing the proteome of gestational UF. It is not clear whether different forms of $\beta$-actin originate because of a possible proteolytic action in the UF or whether these are secreted as such from the embryo or endometrium during the embryo attachment stage. In 1D immunoblots, truncated actin fragments (of 38 and $20 \mathrm{kDa}$, as observed in the 2D gels) were not detected. This could be attributed to immunoprobing of $1 \mathrm{D}$ blots with a MAB directed against an N-terminal epitope, probably absent in the truncated fragments of $\beta$-actin.

To sum up, the study investigated proteomic alterations in the rat UF during the period when there is a maximum likelihood of embryos getting implanted in a nonconception cycle. Several proteins, not reported earlier for their presence in the rat UF, have been identified. Some of the proteins showed the similar pattern of abundance in the receptive phase, to that reported in humans. The study also led to the identification of proteins that are differentially secreted in the gestational UF, during the embryo attachment stage. It will be of interest to investigate whether modulation in the levels of specific protein influences embryonic development and/or implantation and whether any of these can be used as an indicator of the functional normalcy of embryo and/or endometrium.

\section{Supplementary data}

This is linked to the online version of the paper at http://dx.doi. org/10.1530/REP-12-0461.

\section{Declaration of interest}

The authors declare that there is no conflict of interest that could be perceived as prejudicing the impartiality of the research reported.

\section{Funding}

The study was supported by the Indian Council of Medical Research.

\section{Acknowledgements}

The authors acknowledge the financial support received from Indian Council of Medical Research and Department of Biotechnology, Government of India. The authors are thankful to Dr Surekha Zingde (Deputy Director, ACTREC, Kharghar, Navi Mumbai) and Dr Rukmani Govekar and Mr Shashidhar Dolas for their help in MALDI-TOF-TOF analysis of 2D spots. The authors also thank Dr A A Natu and Ms Mayura Nakade for their help in MALDI-TOF/TOF analysis at Indian Institute of Science, Education and Research (IISER), Pune, India. TCGA (The Centre for Genomic Applications), New Delhi, is thanked for LCMS/MS analysis. Mr SB thanks the Department of Biotechnology, Government of India, and the Indian Council of Medical Research for providing him the Junior and Senior Research Fellowship respectively.

\section{References}

Aguilar J \& Reyley M 2005 The uterine tubal fluid: secretion, composition and biological effects. Animal Reproduction 2 91-105.

Aplin JD, Hey NA \& Li TC 1996 MUC1 as a cell surface and secretory component of endometrial epithelium: reduced levels in recurrent miscarriage. American Journal of Reproductive Immunology $\mathbf{3 5}$ 261-266. (doi:10.1111/j.1600-0897.1996.tb00042.x)

Bazer FW, Kim J, Ka H, Johnson GA, Wu G \& Song G 2012 Select nutrients in the uterine lumen of sheep and pigs affect conceptus development. Journal of Reproduction and Development 58 180-188. (doi:10.1262/ jrd.2011-019)

Bedaiwy M, Shahin AY, AbulHassan AM, Goldberg JM, Sharma RK, Agarwal A \& Falcone T 2007 Differential expression of follicular fluid cytokines: relationship to subsequent pregnancy in IVF cycles. Reproductive BioMedicine Online 15 321-325. (doi:10.1016/S14726483(10)60346-X)

Beier HM 1974 Oviducal and uterine fluids. Journal of Reproduction and Fertility 37 221-237. (doi:10.1530/jrf.0.0370221)

Bradford MM 1976 A rapid and sensitive method for the quantitation of microgram quantities of protein utilizing the principle of protein-dye binding. Analytical Biochemistry 72 248-254. (doi:10.1016/00032697(76)90527-3)

Burton GJ, Watson AL, Hempstock J, Skepper JN \& Jauniaux E 2002 Uterine glands provide histiotrophic nutrition for the human fetus during the first trimester of pregnancy. Journal of Clinical Endocrinology and Metabolism 87 2954-2959. (doi:10.1210/jc.87.6.2954)

Casado-Vela J, Rodriguez-Suarez E, Iloro I, Ametzazurra A, Alkorta N, Garcia-Velasco JA, Matorras R, Prieto B, Gonzalez S, Nagore D et al. 
2009 Comprehensive proteomic analysis of human endometrial fluid aspirate. Journal of Proteome Research 8 4622-4632. (doi:10.1021/ pr9004426)

Chen JI, Hannan NJ, Mak Y, Nicholls PK, Zhang J, Rainczuk A, Stanton PG, Robertson DM, Salamonsen LA \& Stephens AN 2009 Proteomic characterization of midproliferative and midsecretory human endometrium. Journal of Proteome Research 8 2032-2044. (doi:10.1021/ pr801024g)

Denker HW 1994 Endometrial receptivity: cell biological aspects of an unusual epithelium. A review. Annals of Anatomy 176 53-60. (doi:10.1016/S0940-9602(11)80416-4)

Gray CA, Burghardt RC, Johnson GA, Bazer FW \& Spencer TE 2002 Evidence that absence of endometrial gland secretions in uterine gland knockout ewes compromises conceptus survival and elongation. Reproduction 124 289-300. (doi:10.1530/rep.0.1240289)

Guerin P, El Mouatassim S \& Menezo Y 2001 Oxidative stress and protection against reactive oxygen species in the pre-implantation embryo and its surroundings. Human Reproduction Update 7 175-189. (doi:10.1093/humupd/7.2.175)

Hafez ES 1977 Kinetics of luminal secretions in the female reproductive tract. Ultrastructural and physiological parameters. Acta Anatomica 97 143-146. (doi:10.1159/000144727)

Hafez ES, Barnhart MI, Ludwig H, Lusher J, Joelsson I, Daniel JL, Sherman AI, Jordan JA, Wolf H, Stewart WC et al. 1975 Scanning electron microscopy of human reproductive physiology. Acta Obstetricia et Gynecologica Scandinavica. Supplement 40 1-61. (doi:10.3109/ $00016347509156419)$

Hafez ES, Fadel HE, Noonan SM, Oshima M, Okamura H, Watson JH, Zaneveld LJ \& Steger RW 1977 Scanning electron microscopy of human female reproductive tract and amniotic fluid cells. International Journal of Fertility 22 193-205.

Hall A \& Nobes CD 2000 Rho GTPases: molecular switches that control the organization and dynamics of the actin cytoskeleton. Philosophical Transactions of the Royal Society of London. Series B: Biological Sciences 355 965-970. (doi:10.1098/rstb.2000.0632)

Halperin R, Halpern D, Hadas E, Bukovsky I \& Schneider D 1998 Intrauterine levels of human decidua-associated protein (hDP) 200 in normal pregnancy and missed abortion. Gynecologic and Obstetric Investigation 46 150-152. (doi:10.1159/000010022)

Hannan NJ, Stephens AN, Rainczuk A, Hincks C, Rombauts LJ \& Salamonsen LA 2010 2D-DiGE analysis of the human endometrial secretome reveals differences between receptive and nonreceptive states in fertile and infertile women. Journal of Proteome Research 9 6256-6264. (doi:10.1021/pr1004828)

Hannan NJ, Paiva P, Meehan KL, Rombauts LJ, Gardner DK \& Salamonsen LA 2011 Analysis of fertility-related soluble mediators in human uterine fluid identifies VEGF as a key regulator of embryo implantation. Endocrinology 152 4948-4956. (doi:10.1210/en.20111248)

Heng YJ, Di Quinzio MK, Permezel M, Rice GE \& Georgiou HM 2008 Interleukin-1 receptor antagonist in human cervicovaginal fluid in term pregnancy and labor. American Journal of Obstetrics and Gynecology 656 e651-e657. (doi:10.1016/j.ajog.2008.06.011)

Heng S, Hannan NJ, Rombauts LJ, Salamonsen LA \& Nie G 2011 PC6 levels in uterine lavage are closely associated with uterine receptivity and significantly lower in a subgroup of women with unexplained infertility. Human Reproduction 26 840-846. (doi:10.1093/humrep/der002)

Hoversland RC \& Weitlauf HM 1982 In-vitro zona-lytic activity in uterine fluid from ovariectomized mice treated with oestradiol-17 $\beta$ and progesterone. Journal of Reproduction and Fertility 64 223-226. (doi:10.1530/jrf.0.0640223)

Immenschuh S \& Baumgart-Vogt E 2005 Peroxiredoxins, oxidative stress, and cell proliferation. Antioxidants \& Redox Signaling 7 768-777. (doi:10.1089/ars.2005.7.768)

Inagaki N, Stern C, McBain J, Lopata A, Kornman L \& Wilkinson D 2003 Analysis of intra-uterine cytokine concentration and matrix-metalloproteinase activity in women with recurrent failed embryo transfer. Human Reproduction 18 608-615. (doi:10.1093/humrep/deg139)
Jarkovska K, Martinkova J, Liskova L, Halada P, Moos J, Rezabek K, Gadher SJ \& Kovarova H 2010 Proteome mining of human follicular fluid reveals a crucial role of complement cascade and key biological pathways in women undergoing in vitro fertilization. Journal of Proteome Research 9 1289-1301. (doi:10.1021/pr900802u)

Joshi MS, Yaron A \& Lindner HR 1970 An endopeptidase in the uterine secretion of the proestrous rat and its relation to a sperm decapitating factor. Biochemical and Biophysical Research Communications 38 52-57. (doi:10.1016/0006-291X(70)91082-X)

Jozwik M, Wolczynski S \& Szamatowicz M 1999 Oxidative stress markers in preovulatory follicular fluid in humans. Molecular Human Reproduction 5 409-413. (doi:10.1093/molehr/5.5.409)

Keeler SM, Kiefer DG, Rust OA, Vintzileos A, Atlas RO, Bornstein E \& Hanna N 2009 Comprehensive amniotic fluid cytokine profile evaluation in women with a short cervix: which cytokine(s) correlates best with outcome? American Journal of Obstetrics and Gynecology 276 e271-e276. (doi:10.1016/j.ajog.2009.05.045)

Kirby DR 1962 The influence of the uterine environment on the development of mouse eggs. Journal of Embryology and Experimental Morphology 10 496-506.

Koch JM, Ramadoss J \& Magness RR 2010 Proteomic profile of uterine luminal fluid from early pregnant ewes. Journal of Proteome Research $\mathbf{9}$ 3878-3885. (doi:10.1021/pr100096b)

Lee RS, Wheeler TT \& Peterson AJ 1998 Large-format, two-dimensional polyacrylamide gel electrophoresis of ovine periimplantation uterine luminal fluid proteins: identification of aldose reductase, cytoplasmic actin, and transferrin as conceptus-synthesized proteins. Biology of Reproduction 59 743-752. (doi:10.1095/biolreprod59.4.743)

Mackenna A, Li TC, Dalton C, Bolton A \& Cooke I 1993 Placental protein 14 levels in uterine flushing and plasma of women with unexplained infertility. Fertility and Sterility 59 577-582.

Mikolajczyk M, Wirstlein P \& Skrzypczak J 2006 Leukaemia inhibitory factor and interleukin 11 levels in uterine flushings of infertile patients with endometriosis. Human Reproduction 21 3054-3058. (doi:10.1093/ humrep/del225)

Parmar T, Sachdeva G, Savardekar L, Katkam RR, Nimbkar-Joshi S, Gadkar-Sable S, Salvi V, Manjramkar DD, Meherji P \& Puri CP 2008 Protein repertoire of human uterine fluid during the midsecretory phase of the menstrual cycle. Human Reproduction 23 379-386. (doi:10.1093/humrep/dem367)

Parr EL, Tung HN \& Parr MB 1987 Apoptosis as the mode of uterine epithelial cell death during embryo implantation in mice and rats. Biology of Reproduction 36 211-225. (doi:10.1095/biolreprod36.1.211)

Salleh N, Baines DL, Naftalin RJ \& Milligan SR 2005 The hormonal control of uterine luminal fluid secretion and absorption. Journal of Membrane Biology 206 17-28. (doi:10.1007/s00232-005-0770-7)

Scotchie JG, Fritz MA, Mocanu M, Lessey BA \& Young SL 2009 Proteomic analysis of the luteal endometrial secretome. Reproductive Sciences $\mathbf{1 6}$ 883-893. (doi:10.1177/1933719109337165)

Shevchenko A, Wilm M, Vorm O \& Mann M 1996 Mass spectrometric sequencing of proteins silver-stained polyacrylamide gels. Analytical Chemistry 68 850-858. (doi:10.1021/ac950914h)

Tsangaris GT, Karamessinis P, Kolialexi A, Garbis SD, Antsaklis A, Mavrou A \& Fountoulakis M 2006 Proteomic analysis of amniotic fluid in pregnancies with Down syndrome. Proteomics 6 4410-4419. (doi:10.1002/pmic.200600085)

Zegels G, Van Raemdonck GA, Coen EP, Tjalma WA \& Van Ostade XW 2009 Comprehensive proteomic analysis of human cervical-vaginal fluid using colposcopy samples. Proteome Science 7 17. (doi:10.1186/ 1477-5956-7-17)

Received 15 November 2012

First decision 20 December 2012

Revised manuscript received 5 April 2013

Accepted 30 April 2013 